\title{
PHYSICAL ACTIVITY, CYSTIC EROSIONS, AND OSTEOPOROSIS IN RHEUMATOID ARTHRITIS*
}

BY

\author{
B. A. CASTillo, R. A. El SAllab, and J. T. SCOTT \\ Department of Medicine, Postgraduate Medical School, London
}

It was noted by Bywaters (1964) that cystic changes in rheumatoid joints occur especially "in people who have little pain, strong muscles, and heavy jobs, so that they continue at work despite their rheumatoid arthritis, and the intermittently increased intraarticular pressure due to work drives synovial fluid into the bone marrow spaces in a similar way to that seen in degenerative joint disease, especially of the hip. Patients with many and large cysts usually give a history of never having lost a day's work."

These patients retain a fair degree of bone calcification. Those whose limbs fall into disuse because of pain develop relatively shallow erosions and severe osteoporosis.

The present study attempts to test this impression by examining the relation between these factors.

\footnotetext{
* Presented at a meeting of the Heberden Society on February 26
} 1965.

\begin{abstract}
Methods
Hand radiographs from 204 unselected hospital patients with rheumatoid arthritis were inspected; 51 were discarded because the radiological severity of the disease was not sufficient for the purpose of the study, and the 153 films finally examined and graded were all from patients who had been found clinically to have classical or definite rheumatoid arthritis (A.R.A. criteria, Ropes, Bennett, Cobb, Jacox, and Jessar, 1959), the films themselves showing erosive changes of moderate or severe degree (Grades 3 and 4 as defined in "The Epidemiology of Chronic Rheumatism", C.I.O.M.S., 1963). Without knowledge of the patient's identity, all films were graded for degree of depth or cystic change shownô by the erosions, the grades being I = slight, II $=$ moder ate, III = severe. Examples of each grade are shown ino Fig. 1. As will be shown later, more advanced degrees of? cystic change were seen in some radiographs than are present in Fig. $1(c)$, but these three films are reproduced here because they were used as standards when assessing the others.
\end{abstract}

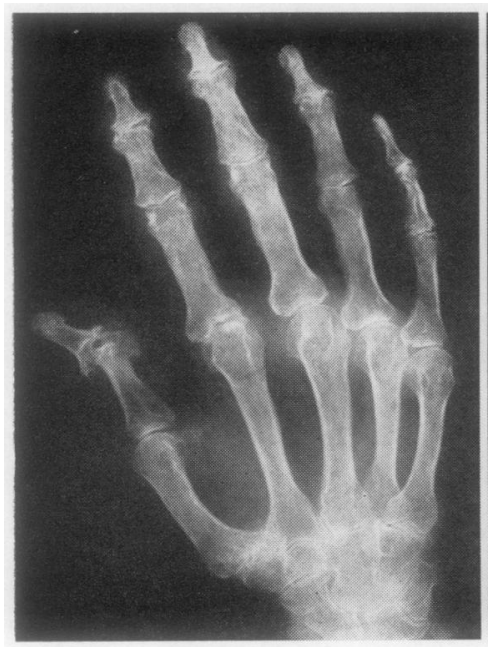

(a)

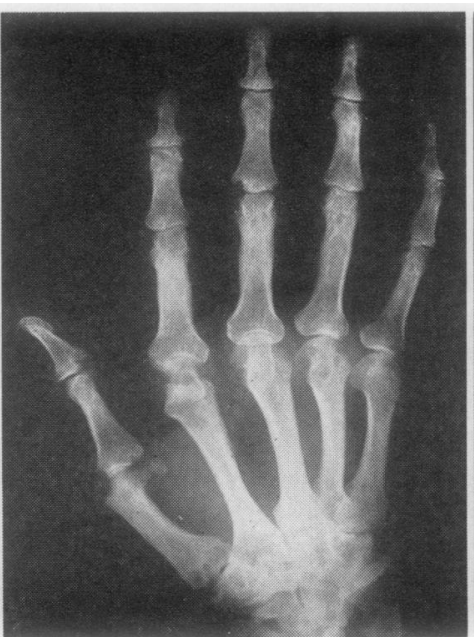

(b)

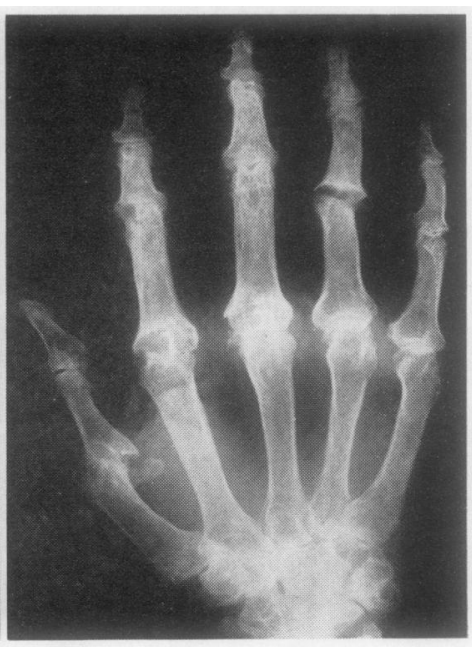

(c)

Fig. 1.-Degrees of cystic change in rheumatoid erosions. (a) Grade I (Mild); (b) Grade II (Moderate); (c) Grade III (Severe). 
The 153 radiographs were assessed separately for degree of osteoporosis, the same three grades ( $\mathrm{I}=$ slight, II = moderate, and III = severe) being used.

The patients' hospital records were examined without knowledge of the radiological assessment and each patient was graded for degree of physical activity:

Grade I: Incapacitated with very little use of hands.

Grade II: Leading moderately active life but without strenuous use of hands.

Grade III: Leading very active life and using hands for hard manual work.

This grading was made without difficulty in most cases. Details of each patient's D.A.T. (differential agglutination titre: Rose, Ragan, Pearce, and Lipman, 1948) were abstracted at the same time, together with information whether treatment with corticosteroid hormones was being given or not.

The gradings for cystic change and for osteoporosis were compared with each other, and the gradings for each were compared with those for physical activity, sex, D.A.T., and steroid treatment.

\section{Results}

(1) Cystic Changes and Osteoporosis (Table 1).This shows a significant inverse relation between degree of cystic change and that of porosis $\left(\chi^{2}=\right.$ $44 \cdot 3 ; \mathrm{P}=<0 \cdot 001)$, i.e. films showing most evidence of deep cystic erosions showed least porosis and vice versa. It is true that the 32 films showing only Grade I porosis were equally distributed among the three grades of cystic change; but, of the 39 showing Grade III porosis, 35 fell in Grade I of cystic change, 4 in Grade II, and none in Grade III.

(2) Cystic Changes and Physical Activity (Table II).-This shows a significant positive relation between the degrees of cystic change and physical activity $\left(\chi^{2}=61 \cdot 5 ; \mathrm{P}=<0.001\right)$. Of the twenty patients showing Grade III cystic erosions, fourteen were performing Grade III physical activity, six Grade II, and none Grade I.

(3) Osteoporosis and Physical Activity (Table III).- There is a significant inverse relation between the grades of osteoporosis and physical activity $\left(\chi^{2}=68.0 ; \mathrm{P}=<0.001\right)$, i.e. films showing most porosis tended to be those of patients undertaking least physical activity and vice versa.

TABLE I

RELATIONSHIP OF CYSTIC CHANGE TO OSTEOPOROSIS

\begin{tabular}{|c|c|c|c|c|c|c|c|c|c|}
\hline \multirow{2}{*}{\multicolumn{6}{|c|}{ Grade of Cystic Change }} & \multicolumn{4}{|c|}{ Grade of Osteoporosis } \\
\hline & & & & & & (Mild) & II & (Severe) & Total \\
\hline $\begin{array}{l}\text { I (Mild) . } \\
\text { II (Moderate) } \\
\text { III (Severe) }\end{array}$ & $\begin{array}{l}\cdots \\
\cdots \\
\cdots\end{array}$ & $\begin{array}{l}\cdots \\
\cdots \\
\cdots\end{array}$ & $\begin{array}{l}\cdots \\
\cdots\end{array}$ & $\begin{array}{l}\cdots \\
\cdots \\
\cdots\end{array}$ & $\begin{array}{l}\cdots \\
\cdots \\
\cdots\end{array}$ & $\begin{array}{l}11 \\
11 \\
10\end{array}$ & $\begin{array}{l}29 \\
43 \\
10\end{array}$ & $\begin{array}{r}35 \\
4 \\
0\end{array}$ & $\begin{array}{l}75 \\
58 \\
20\end{array}$ \\
\hline Total & $\cdots$ & $\cdots$ & $\cdots$ & $\cdots$ & $\cdots$ & 32 & 82 & 39 & 153 \\
\hline \multicolumn{10}{|c|}{$\begin{array}{c}\text { TABLE II } \\
\text { RELATIONSHIP OF CYSTIC CHANGE TO ACTIVITY OF PATIENT }\end{array}$} \\
\hline \multirow{2}{*}{\multicolumn{6}{|c|}{ Grade of Cystic Change }} & \multicolumn{4}{|c|}{ Grade of Physical Activity } \\
\hline & & & & & & (Low) & $\stackrel{\text { II }}{\text { (Moderate) }}$ & (High) & Total \\
\hline $\begin{array}{l}\text { I (Mild) .. } \\
\text { II (Moderate) } \\
\text { III (Severe) }\end{array}$ & $\begin{array}{l}\ldots \\
\cdots \\
\cdots\end{array}$ & $\begin{array}{l}\cdots \\
\cdots\end{array}$ & $\begin{array}{l}\cdots \\
\cdots \\
\cdots\end{array}$ & $\begin{array}{l}\cdots \\
\cdots \\
\cdots\end{array}$ & $\begin{array}{l}\cdots \\
\cdots \\
\end{array}$ & $\begin{array}{r}33 \\
4 \\
0\end{array}$ & $\begin{array}{r}38 \\
43 \\
6\end{array}$ & $\begin{array}{r}4 \\
11 \\
14\end{array}$ & $\begin{array}{l}75 \\
58 \\
20\end{array}$ \\
\hline Total $\ldots$ & $\cdots$ & $\cdots$ & $\ldots$ & . & $\cdots$ & 37 & 87 & 29 & 153 \\
\hline
\end{tabular}

TABLE III

RELATIONSHIP OF OSTEOPOROSIS TO ACTIVITY OF PATIENT

\begin{tabular}{|c|c|c|c|c|c|c|c|c|c|}
\hline \multirow{2}{*}{\multicolumn{6}{|c|}{ Grade of Osteoporosis }} & \multicolumn{4}{|c|}{ Grade of Physical Activity } \\
\hline & & & & & & $\begin{array}{l}\text { I } \\
\text { (Low) }\end{array}$ & $\underset{\text { (Moderate) }}{\text { II }}$ & (III & Tota \\
\hline $\begin{array}{l}\text { I (Mild) .. } \\
\text { II (Moderate) } \\
\text { III (Severe) }\end{array}$ & $\begin{array}{l}\cdots \\
\cdots\end{array}$ & $\begin{array}{l}\cdots \\
\cdots\end{array}$ & $\begin{array}{l}\cdots \\
\cdots\end{array}$ & $\begin{array}{l}\cdots \\
\cdots\end{array}$ & $\begin{array}{l}\cdots \\
\cdots\end{array}$ & $\begin{array}{r}0 \\
10 \\
27\end{array}$ & $\begin{array}{l}20 \\
56 \\
11\end{array}$ & $\begin{array}{r}12 \\
16 \\
1\end{array}$ & $\begin{array}{l}32 \\
82 \\
39\end{array}$ \\
\hline Total .. & . & . & . & .. & $\ldots$ & 37 & 87 & 29 & 153 \\
\hline
\end{tabular}


(4) Physical Activity, Cystic Erosions, Osteoporosis, and Sex (Tables IV, V, and VI).-In the lowest grade of physical activity (Grade I) there was a preponderence of women, and in the highest grade (Grade III) a preponderance of men (Table IV: $\left.\chi^{2}=23.96 ; \mathrm{P}=<0.001\right)$.

TABLE IV

RELATIONSHIP OF SEX TO PHYSICAL ACTIVITY

\begin{tabular}{|c|c|c|c|c|c|c|}
\hline \multirow{2}{*}{\multicolumn{4}{|c|}{ Grade of Physical Activity }} & \multicolumn{3}{|c|}{ Sex } \\
\hline & & & & \multirow{2}{*}{$\begin{array}{c}\text { Male } \\
6 \\
18 \\
17\end{array}$} & \multirow{2}{*}{$\begin{array}{c}\text { Female } \\
31 \\
69 \\
12\end{array}$} & \multirow{2}{*}{$\begin{array}{c}\text { Total } \\
37 \\
87 \\
29\end{array}$} \\
\hline $\begin{array}{l}\text { I (Low) } \\
\text { II (Moderate) } \\
\text { III (High) }\end{array}$ & $\begin{array}{l}\cdots \\
\cdots\end{array}$ & $\begin{array}{l}\cdots \\
\cdots\end{array}$ & $\begin{array}{l}\cdots \\
\cdots \\
\cdots\end{array}$ & & & \\
\hline Total . . & $\ldots$ & .. & $\ldots$ & 41 & 112 & 153 \\
\hline
\end{tabular}

There was a corresponding majority of men in those showing Grade III cystic changes (Table V: $\left.\chi^{2}=32 \cdot 29 ; \mathrm{P}=<0 \cdot 001\right)$.

TABle $V$

RELATIONSHIP OF SEX TO GRADE OF CYSTIC CHANGE

\begin{tabular}{|c|c|c|c|c|c|c|}
\hline \multirow{2}{*}{\multicolumn{4}{|c|}{ Grade of Cystic Change }} & \multicolumn{3}{|c|}{ Sex } \\
\hline & & & & Male & Female & Total \\
\hline $\begin{array}{l}\text { I (Mild) . } \\
\text { II (Moderate) } \\
\text { III (Severe) }\end{array}$ & $\ddot{\cdots}$ & $\begin{array}{l}\ddot{*} \\
\cdots\end{array}$ & $\begin{array}{l}\ddot{ } \\
\ddot{*}\end{array}$ & $\begin{array}{l}11 \\
15 \\
15\end{array}$ & $\begin{array}{r}64 \\
43 \\
5\end{array}$ & $\begin{array}{l}75 \\
58 \\
20\end{array}$ \\
\hline Total .. & $\ldots$ & $\ldots$ & $\ldots$ & 41 & 112 & 153 \\
\hline
\end{tabular}

There was a majority of women in all three grades of osteoporosis, but this was much greater in Grade III than in Grades I and II (Table VI: $\chi^{2}=9 \cdot 95$; $0.01>P>0.001$ ).

TABLE VI

RELATIONSHIP OF SEX TO GRADE OF OSTEOPOROSIS

\begin{tabular}{|c|c|c|c|c|c|c|}
\hline \multirow{2}{*}{\multicolumn{4}{|c|}{ Grade of Osteoporosis }} & \multicolumn{3}{|c|}{ Sex } \\
\hline & & & & Male & Female & Total \\
\hline $\begin{array}{l}\text { I (Mild) . } \\
\text { II (Moderate) } \\
\text { III (Severe) }\end{array}$ & $\begin{array}{l}\ddot{*} \\
\cdots\end{array}$ & $\begin{array}{l}\cdots \\
\cdots\end{array}$ & $\begin{array}{l}\cdots \\
\cdots\end{array}$ & $\begin{array}{r}13 \\
25 \\
3\end{array}$ & $\begin{array}{l}19 \\
57 \\
36 \\
\end{array}$ & $\begin{array}{l}32 \\
82 \\
39 \\
\end{array}$ \\
\hline Total ... & $\ldots$ & . & $\ldots$ & 41 & 112 & 153 \\
\hline
\end{tabular}

(5) Cystic Erosions and Corticosteroid Treatment (Table VII).-Corticosteroid treatment usually consisted of prednisolone in a dosage of between 5 and $10 \mathrm{mg}$. daily. Of the twenty patients with Grade III cystic changes, four were taking steroids and sixteen were not, a lower ratio than in Grades I and II. These numbers, however, are not statistically significant $\left(\chi^{2}=2 \cdot 17 ; 0.5>P>0.3\right)$.
TABle VII

RELATIONSHIP OF CYSTIC CHANGE TO STEROID TREATMENT

\begin{tabular}{|c|c|c|c|c|c|c|}
\hline \multirow{2}{*}{\multicolumn{4}{|c|}{ Grade of Cystic Change }} & \multicolumn{3}{|c|}{ Treatment } \\
\hline & & & & $\begin{array}{l}\text { With } \\
\text { Steroids }\end{array}$ & $\begin{array}{l}\text { Without } \\
\text { Steroids }\end{array}$ & Total \\
\hline $\begin{array}{l}\text { I (Mild) . . } \\
\text { II (Moderate) } \\
\text { III (Severe) }\end{array}$ & $\begin{array}{l}\cdots \\
\cdots\end{array}$ & $\begin{array}{l}. \\
\cdots \\
.\end{array}$ & $\begin{array}{l}\cdots \\
\cdots \\
\cdots\end{array}$ & $\begin{array}{r}26 \\
20 \\
4\end{array}$ & $\begin{array}{l}49 \\
38 \\
16\end{array}$ & $\begin{array}{l}75 \\
58 \\
20\end{array}$ \\
\hline Total ... & $\ldots$ & $\ldots$ & $\ldots$ & 50 & 103 & 153 \\
\hline
\end{tabular}

(6) Osteoporosis and Corticosteroid Treatment (Table VIII).-Although again the figures do not achieve statistical significance $\left(\chi^{2}=4 \cdot 15 ; 0 \cdot 2>\right.$ $P>0 \cdot 1)$, the proportions of patients found to be on steroid treatment rose with increasing severity of osteoporosis.

TABLE VIII

RELATIONSHIP OF OSTEOPOROSIS TO STEROID TREATMENT

\begin{tabular}{|c|c|c|c|c|c|c|}
\hline \multirow{2}{*}{\multicolumn{4}{|c|}{ Grade of Osteoporosis }} & \multicolumn{3}{|c|}{ Treatment } \\
\hline & & & & \multirow{2}{*}{$\begin{array}{c}\begin{array}{c}\text { With } \\
\text { Steroids }\end{array} \\
\begin{array}{c}6 \\
27 \\
17\end{array}\end{array}$} & \multirow{2}{*}{$\begin{array}{c}\begin{array}{c}\text { Without } \\
\text { Steroids }\end{array} \\
26 \\
55 \\
22\end{array}$} & \multirow{2}{*}{$\begin{array}{c}\text { Total } \\
32 \\
\mathbf{8 2} \\
39\end{array}$} \\
\hline $\begin{array}{l}\text { I (Mild) . . } \\
\text { II (Moderate) } \\
\text { III (Severe) }\end{array}$ & $\begin{array}{l}\cdots \\
\therefore \\
\end{array}$ & $\begin{array}{l}\cdots \\
\cdots \\
\cdots\end{array}$ & $\begin{array}{l}\ldots \\
\cdots \\
\cdots\end{array}$ & & & \\
\hline Total .. & $\cdots$ & . & $\cdots$ & 50 & 103 & 153 \\
\hline
\end{tabular}

(7) Cystic Erosions, Osteoporosis, and D.A.T.D.A.T. results were taken from only 149 patients because they were discrepant in the other four. There was no relation between D.A.T. and cystic erosions $\left(\chi^{2}=2.3 ; 0.5>\mathbf{P}>0.3\right)$ or osteoporosis $\left(\chi^{2}=\right.$ $1 \cdot 46 ; 0.5>P>0 \cdot 3)$.

\section{Discussion}

It is clear that large cystic erosions of the hands in rheumatoid arthritis are related to the individual's physical activity. They probably occur as a result of raised intra-articular pressure forcing synovial fluid or granulation tissue deeply into the substance of medullary bone. Erosions of this sort can form in any of the joints of the hands or wrist. They are seen most often in the metacarpophalangeal joints, especially the second and third, the metacarpal head being involved more frequently than the base of the proximal phalanx (Fig. 2). Similar but smaller erosions occur in the interphalangeal joints. They are also seen in the carpus and wrist, especially at the carpal surfaces of the radius and ulna, and at the inferior radio-ulnar articulation (Fig. 3). 
(a)
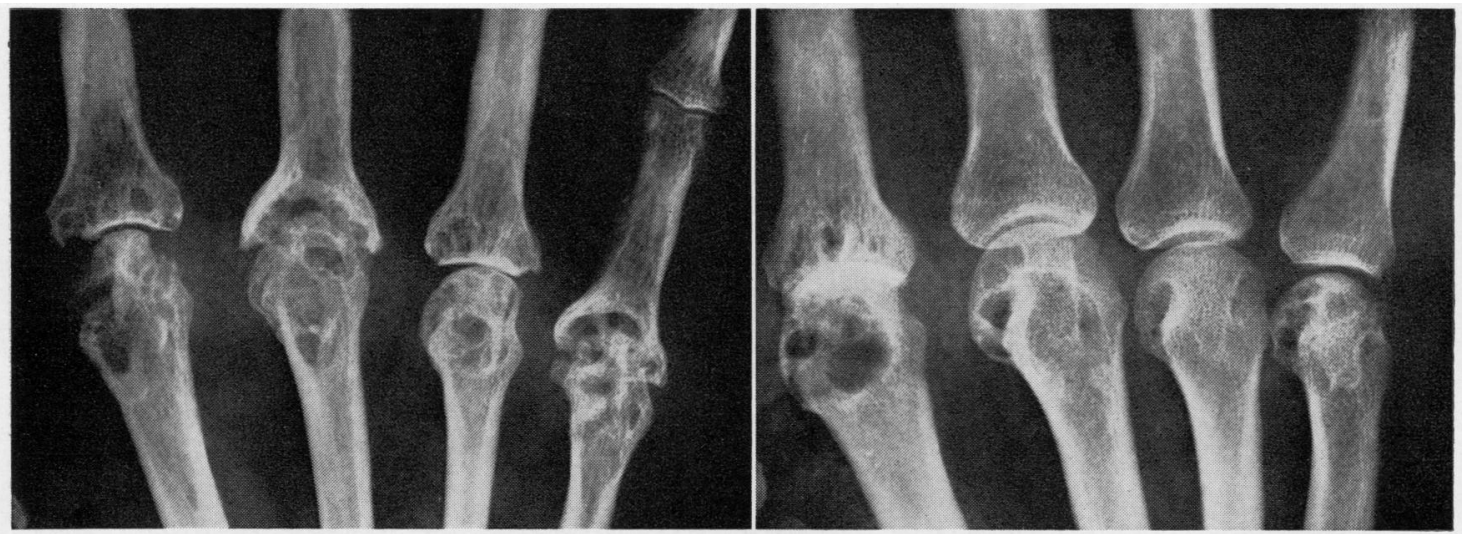

Fig. 2.-Metacarpophalangeal joints from (a) a school teacher and (b) a railway porter, who had persisted at their work over many years despite severe rheumatoid disease.

$(a)$

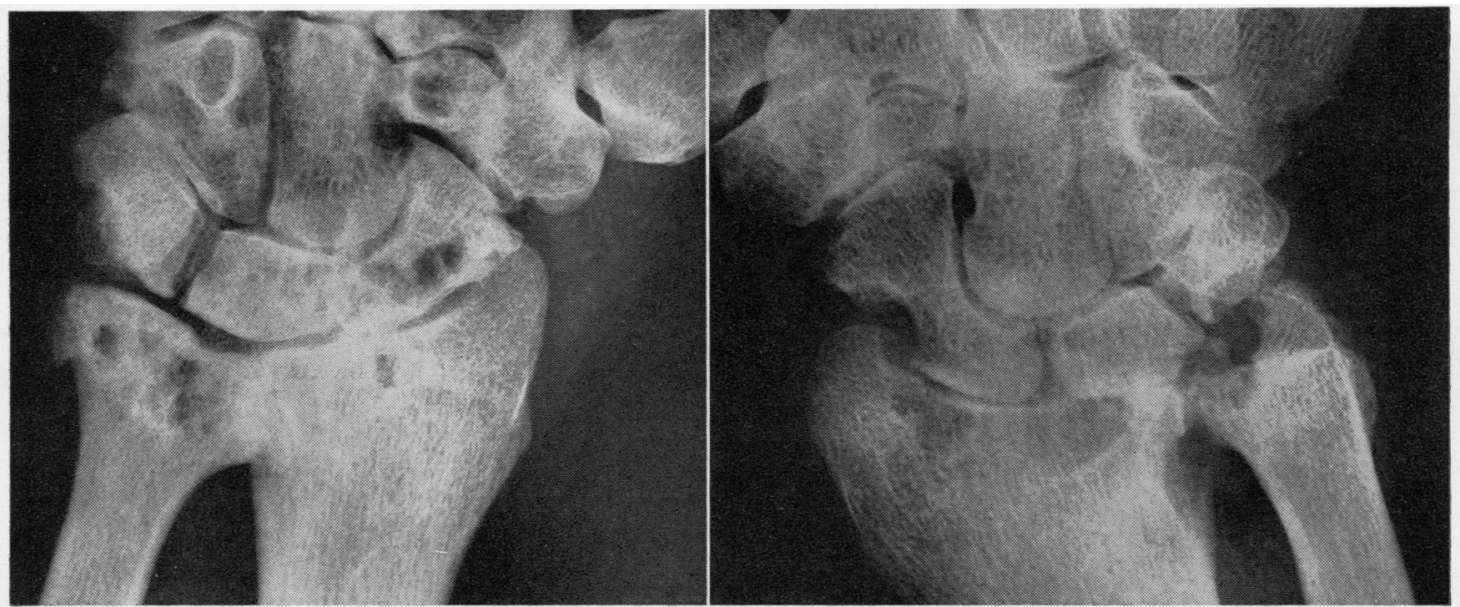

Fig. 3.-Carpal and wrist joints from (a) the railway porter seen in Fig. $2 b$, and (b) a truck driver, showing cystic erosions in the carpal bones and in the lower end of the radius and ulna.

Large cystic erosions are seen in joints other than the hands and wrists, particularly in the knees. Fig. 4 shows, for example, a radiograph of the right knee from a man aged 50, whose job as a television engineer involved a good deal of kneeling, in which he persisted, despite severe rheumatoid arthritis. Caughey and Bywaters (1963) showed that, in kneejoints containing small quantities of fluid, the mean pressures at rest lie between 6 and $33 \mathrm{~mm}$. $\mathrm{Hg}$, rising with muscle contraction and weight-bearing. Dixon and Grant (1964) obtained pressures of over $1,000 \mathrm{~mm}$. $\mathrm{Hg}$ during weight-bearing flexion of the knees. Comparable studies in the joints of the hand and wrist have not been carried out, but one must suppose that intra-articular pressure in these joints during active hand movements such as gripping and grasping rises in a similar way.

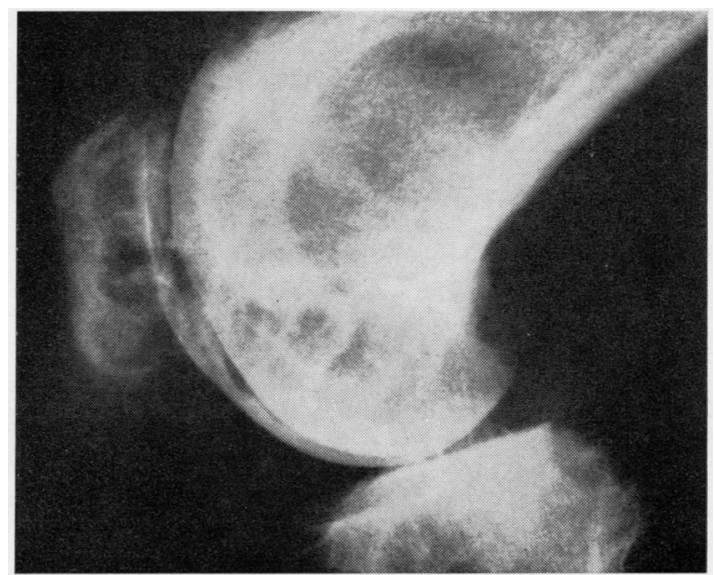

Fig. 4.-Lateral radiograph of the knee of a television engineer with rheumatoid arthritis, showing very large cystic erosions. 
The inverse relationship between osteoporosis and physical activity observed in this study requires little comment. Disuse osteoporosis is well known to occur in many local and general situations: mechanical strain appears to be a normal stimulus to osteoblastic activity.

The fact that most subjects performing the highest grade of manual activity were men accords with the finding that large cystic erosions are a mainly male characteristic and severe osteoporosis a mainly female one.

There was some association of corticosteroid therapy with less pronounced cystic changes and with greater osteoporosis in the hands. Even if this is a valid relationship (and the figures obtained were not statistically significant) the association is probably one of incapacitating disease and consequent corticosteroid therapy rather than one of immediate cause and effect of steroids themselves; although the direct action of these drugs in producing osteoporosis may have played some part.

\section{Summary}

An analysis of the hand radiographs from 153 patients with rheumatoid arthritis led to the conclusion that there is a close relationship between the degree of physical activity and the development of large cystic erosions. These two factors are inversely related to osteoporosis. Cystic erosions are seen more often in men, who perform higher grades of manual activity than women.

\section{REFERENCES}

Bywaters, E. G. L. (1964). "The Hand", In "Radiological Aspects of Rheumatoid Arthritis", edited by M. E. Carter [Int. Congr. Ser. No. 61], p. 43. Excerpta Medica Foundation, Amsterdam.

Caughey, D. E., and Bywaters, E. G. L. (1963). Ann. rheum. Dis., 22, 106.

Council for International Organizations of Medical Sciences (1963). "The Epidemiology of Chronic Rheumatism", vol. 2, "Atlas of Standard Radiographs of Arthritis", prepared by the Department of Rheumatology and Medical Illustration, University of Manchester, and Manchester Royal Infirmary, and the Empire Rheumatism Council's Field Unit. Blackwell, Oxford.

Dixon, A. St. J., and Grant, C. (1964). Lancet, 1, 742.

Ropes, M. W., Bennett, G. A., Cobb, S., Jacox, R., and Jessar, R. A. (1959). Ann. rheum. Dis., 18, 49.

Rose, H. M., Ragan, C., Pearce, E., and Lipman, H. O. (1948). Proc. Soc. exp. Biol. (N.Y.), 68, 1.

\section{Discussion}

DR. J. LAWRENCE (Manchester): In our population surveys we found that a good many $x$ rays showed bone cysts, though most of them were smaller than those shown by Dr. Scott. They were mostly in the metacarpophalangeal joints and in the region of the wrist joint, and there was some doubt regarding their significance. They were obviously quite often present in joints showing evidence of osteo-arthrosis or rheumatoid arthritis, but the great majority were found in the region of joints which showed no evidence of disease at all. We tried to correlate their presence with clinical rheumatoid arthritis but found no relationship whatsoever. They were more common in males and were found most often in heavy manual workers such as miners. It does seem that in those without arthritis there is the same relationship to heavy manual work.

DR. Scort: That is interesting. One would suppose that in rheumatoid arthritis the development of these deep erosions depends on articular cartilage no longer being intact, so that fluid and granulation tissue is driven into the bone. It is rather difficult to understand why they should be found in patients without joint disease.

DR. LAWRENCE: Yes, unless minor injury has caused a small lesion.

DR. J. J. R. DuthIE (Edinburgh): Were any biopsies carried out on these joints? Dr. Cruickshank did some and found them full of granulation tissue.

DR. Scotr: No, but Professor Bywaters once examined some autopsy specimens and I think found both fluid and granulation tissue in these cysts. In our arteriographic studies we have seen them fill with a hyperaemic blush, confirming that they may contain granulation tissue.

DR. A. ST. J. Dxxon (London): I should very much like to see the French word géode used for these cysts. This term can be applied to osteo-arthritis, gout, and rheumatoid arthritis. When joint pressure rises the hypertrophic synovial tissue which is part of the contents of the joint is subjected to the same pressures. The géode acts as a kind of filter and cells and debris are left behind.

Dr. D. A. H. YATES (London): Should we advise our patients to use their rheumatoid hands as actively as possible?

DR. Scotr: I feel sure that this whole question is related to the patient's pain threshold. In general, patients with these large cystic erosions do better than the others and manage to continue with their activities. This is because of their own attitude and not because of any particular treatment they are receiving.

DR. G. D. KersLeY (Bath): In our study of tomograms we found that there was often quite a large opening from these cysts into the joint surface, although on plain $x$ ray they appeared entirely cystic. 


\section{L'activité physique, les érosions cystiques et l'ostéoporose} dans l'arthrite rhumatismale

\section{RÉSUMÉ}

Une analyse des radiographies des mains de 153 malades atteints d'arthrite rhumatismale mène à la conclusion qu'il existe un rapport étroit entre l'intensité de l'activité physique et le développement de grandes érosions cystiques. Ces deux facteurs se trouvent en rapport inverse de l'ostéoporose. Des érosions cystiques se voient plus souvent chez des hommes dont l'activité manuelle est plus grande que celle des femmes.
La actividad física, las erosiones císticas y la osteoporosis en la artritis reumatoide

\section{SUMARIO}

Un análisis de radiografías de las manos de 153 enfermos con artritis reumatoide lleva a la conclusión de que existe una relación estrecha entre la intensidad de la actividad física y el desarrollo de grandes erosiones císticas. Estos dos factores estan inversamente relacionados con la osteoporosis. Las erosiones císticas se ven más frecuentemente en los hombres cuya actividad manual es más intensa que la de las mujeres. 